\title{
Emerging Prognostic Biomarkers in Non Small Cell Lung Cancer Patients: Impact of Treatment with Nimesulide (COX-2 Inhibitor) Combined with Chemotherapy
}

\section{Soad M Abdel Ghany¹, Nagla T El Melegy ${ }^{2}$, Aliae AR Mohamed-Hussein ${ }^{3 *}$ and Randa S Hana ${ }^{4}$}

${ }^{1}$ Professor of Medical Biochemistry, Faculty of Medicine, Assiut University, Assiut, Egypt ${ }^{2}$ Professor of Medical Biochemistry, Faculty of Medicine, Assiut University, Assiut, Egypt

${ }^{3}$ Associate professor of pulmonology, Chest department, Assiut University, Assiut, Egypt

${ }^{4}$ Lecturer of Medical Biochemistry, Faculty of Medicine, Assiut University, Assiut, Egypt

\begin{abstract}
To date, the treatment outcome of non small cell lung cancer (NSCLC) is still not satisfactory and new treatment options are urgently needed. The present study was designed to: 1) evaluate the effects of the antiangiogenic drug; nimesulide (NSAID, a COX-2 inhibitor) combined with chemotherapy on NSCLC treatment progress, 2) Evaluate the role of vascular endothelial growth factor (VEGF) and basic fibroblast growth factor (bFGF), as prognostic indicators in NSCLC, 3) Correlate the above parameters levels with the clinicopathological status of the patients during the therapy. The study included 30 NSCLC. The patients were divided to: group I, included 17 patients received chemotherapy alone and group II included 13 patients received the same chemotherapy with Nimesulide and 10 as controls. Serum and biopsies were taken for all subjects on admission and 3 weeks after the completion of treatment. Results: serum and tissue levels of VEGF and bFGF, were significantly higher in NSCLC patients and decreased significantly after treatment specially in group II compared to group I. The serum and tissue levels of the studied parameters decreased significantly in the responders as compared to resistant cases. The response rate after combined therapy was $69 \%$ versus $53 \%$ after chemotherapy alone. In conclusion, Nimesulide appears to boost the efficacy of the traditional chemotherapy as its co-administration showed encouraging effects on improving and normalization of the proangiogenic parameters levels and in turn the vascular supply of tumors. This may have good impact on the patient outcome, prolongation of their survival rate and prognosis.
\end{abstract}

Keywords: Non-small cell lung cancer; Nimesulide; Cox-2 inhibitor; VEGF; b-FGF; Prognosis

\section{Introduction}

Lung cancer is one of the most frequent and lethal malignancies worldwide, and the 5-year survival rate is only about $20 \%$ [1-2]. Non small cell lung cancer tissue produces numerous growth factors which are multifunctional [3].

Vascular endothelial growth factor (VEGF) and its receptor family play a critical role in cancer progression by mobilizing circulating endothelial cells precursors to the nascent blood vessels [4]. Not only does VEGF promote the vascularization and growth of the primary tumor, but it also appears to play a key role in the establishment of new metastatic foci [5- 6].

Basic fibroblast growth factor (bFGF) is a potent tumor angiogenic factor [7]. It is also involved in the proliferation and differentiation of a variety of normal tissues and malignant transformation [8]. The bFGF provides the potential to predict early-stage NSCLC recurrence after resection [6].

To date, no single agent has gained a sufficient prognostic significance or therapeutic efficacy for NSCLC patients. So, there is an urgent need for new innovative therapies to treat NSCLC [9-10].

The present study was designed to:

1) Evaluate the effects of the antiangiogenic drug; Nimesulide (a NSAID, a selective COX-2 inhibitor) combined with chemotherapy versus chemotherapy alone on NSCLC treatment progress and patients prognosis.

2) Evaluate the role of VEGF and bFGF as prognostic indicators for NSCLC.

3) Investigate the correlation between these biochemical indices and the clinicopathological status of NSCLC patients during the combined therapy.

\section{Patients and Methods}

The present study included a total of 30 patients admitted in Assiut University Hospitals in the period from August 2008 to January 2010 with primary tumors of the newly diagnosed histopathologically proven NSCLC. Their age ranged from $50-70$ years $(55.6 \pm 5.2)$. Their clinical characteristics are shown in (Table 1). All patients were subjected to full history taking, physical examination, routine laboratory investigations as complete blood picture, liver and kidney functions, chest $\mathrm{x}$-ray (postero-anterior and lateral views), and transthoracic ultrasonography (TUS). The final diagnosis of lung cancer was confirmed by fiber-optic bronchoscopic biopsy or percutaneous needle biopsy taken from the lesion guided by TUS or computed tomography (CT) of the chest in patients with peripheral masses refusing bronchoscope (the use of TUS is preferred in our institute for economic reasons, and we have the available apparatus excellent skills).

Patients were excluded from the present study if they had chest

${ }^{*}$ Corresponding author: Dr. Aliae AR Mohamed Hussein, Associate Professo of Pulmonology, Chest Department, Assiut University Hospitals, Assiut, Egypt, E-mail: massah_99@yahoo.com

Received November 14, 2011; Accepted Dececmber 16, 2011; Published Dececmber 18, 2011

Citation: Abdel Ghany SM, El Melegy NT, Mohamed-Hussein AAR, Hana RS (2011) Emerging Prognostic Biomarkers in Non Small Cell Lung Cancer Patients: Impact of Treatment with Nimesulide (COX-2 Inhibitor) Combined with Chemotherapy. J Pulmonar Respirat Med S5:003. doi:10.4172/2161-105X.S5-003

Copyright: (C) 2011 Abdel Ghany SM, et al. This is an open-access article distributed under the terms of the Creative Commons Attribution License, which permits unrestricted use, distribution, and reproduction in any medium, provided the original author and source are credited. 
Citation: Abdel Ghany SM, El Melegy NT, Mohamed-Hussein AAR, Hana RS (2011) Emerging Prognostic Biomarkers in Non Small Cell Lung Cancer Patients: Impact of Treatment with Nimesulide (COX-2 Inhibitor) Combined with Chemotherapy. J Pulmonar Respirat Med S5:003. doi:10.4172/2161-105X.S5-003

Page 2 of 6

infections or tuberculosis, heart diseases, pulmonary secondary, hepatic or renal insufficiency, active GIT bleeding or history of peptic ulcer, malignancies elsewhere or previous treatment for lung cancer. They were classified according to the disease stage into stage IIA (10 cases), stage IIB (13 cases) and stage IIIA ( 7 cases).

Sixteen cases had squamous cell carcinoma, 7 cases had adenocarcinoma and 7 cases had large cell carcinoma. Ten healthy control subjects of matched age and sex were also included in the study. The patients were randomly allocated into two groups: group I included 17 patients who were randomized to receive chemotherapy alone; Vepside $100 \mathrm{mg} / \mathrm{m}^{2}$ and Platinol $25-30 \mathrm{mg} / \mathrm{m}^{2}$ added to $500 \mathrm{ml}$ saline in six cycles, each cycle was repeated every 21 days according to the patient general condition and response to treatment. Group II included 13 patients randomized to receive the same previous chemotherapy combined with COX-2 inhibitor, Nimesulide $5 \mathrm{mg} /$ $\mathrm{Kg}$ t.d.s for 3 weeks. The principal efficacy end point of treatment was the response rate (survival, progression-free survival, reduction in symptoms, or improvement of quality of life. Radiological complete response, the disappearance of all target lesions; partial response, at least a $30 \%$ decrease in the sum of the longest diameter of target lesions, taking as reference the baseline sum longest diameter; progressive disease, at least a $20 \%$ increase in the sum of the longest diameter of target lesions, taking as reference the smallest sum longest diameter recorded since the treatment started or the appearance of one or more new lesions; stable disease, neither sufficient shrinkage to qualify for partial response nor sufficient increase to qualify for progressive disease, taking as reference the smallest sum longest diameter since the treatment started. Bronchoscopic response, regression of tumor size and reduced vascularity), whereas the resistance end-point was determined by tumor related hemoptysis episodes, the time of progression in weeks (rate of tumor growth), tumor recurrence and the survival rate. An informed consent was obtained from all participants in this study and approved by the Ethical Committee of Assiut University.

\section{Blood and tissue samples}

A $10 \mathrm{cc}$ of fasting venous blood was obtained from each participant besides patients lung tissue biopsies both on admission and 3 weeks after the completion of one cycle chemotherapy with or without Nimesulide regimen (if the tumor size allows). Another bronchoscopic biopsy was taken from the pathologically examined non-malignant, non-inflammatory healthy lung tissue and served as a control tissue. The blood samples were centrifuged at $3000 \mathrm{rpm}$ for 15 minutes and the serum samples were stored at $-70{ }^{\circ} \mathrm{C}$ till the time of assay. Tissue samples were washed with ice water and kept frozen at $-70^{\circ} \mathrm{C}$ in liquid nitrogen until used. Tissue samples were homogenized in TED buffer $(10 \mathrm{mM} / \mathrm{L}$ tris, $1.5 \mathrm{mM} / \mathrm{L}$ EDTA- disodium salt and $1.0 \mathrm{mM} / \mathrm{L}$ dithiothreitol, $\mathrm{PH}: 7.4)$ at $4^{\circ} \mathrm{C}$. The buffer was prepared fresh every time and the dithiothreitol was added immediately before use. The tissue homogenate were centrifuged for 30 minutes at $15000 \mathrm{rpm}$ and the supernatant was separated and stored at $-70{ }^{\circ} \mathrm{C}$ till the time of use.

\section{Biochemical assays}

-Serum and tissue VEGF (165 isoform) and bFGF were determined using ELISA kit (Cat No: BC -1021, BC -1011 respectively) supplied by Biocheck, Inc., Canada.

-Tissue protein concentration was determined as described by Lawery et al. [11].

\section{Statistical analysis}

The data were analyzed using the statistical package Version 11;
SPSS AG, USA. For multiple comparisons between the parametric variables, one way analysis of variance (ANOVA) test along with Pearson's correlation were applied. $\mathrm{P}$ value $<0.05$ was considered significant. Patients were randomly allocated into the 2 therapy groups (1:1 cross-over), the outcome assessment was done by a blind observer to the original treatment allocation (the bronchoscopist).

\section{Results}

The present study showed that $53.3 \%$ of NSCLC patients were smokers. Their occupation may have an impact on their lung disease (Male patients were, $58.8 \%$ farmers, $17.6 \%$ cement workers, $17.6 \%$ drivers and $5.8 \%$ shoes maker). Three patients (10\%) developed malignant pleural effusion (they were considered non- responders). The white blood cells count, platelets count and ESR were significantly higher in patients compared to the control levels (Table 1). Serum VEGF was significantly higher in smokers compared to non-smokers (Table 2).

The serum and tissue levels of the studied parameters were significantly higher in patients compared to controls, and significantly decreased after treatment in both groups compared to pretreatment levels. Moreover, these levels were significantly lower in the combined therapy group compared to chemotherapy only (Figure 1).

The serum and tissue levels of the studied biochemical indices were significantly higher in stage IIIA compared to stage IIA and IIB,

\begin{tabular}{|l|l|l|}
\hline VARIABLE & CONTROLS (N=10) & PATIENTS (N=30) \\
\hline Age(years) & $54.22 \pm 5.2$ & $55.60 \pm 5.5$ \\
\hline Male / Female (\%) & $60 / 40$ & $56.7 / 43.3$ \\
\hline Smokers / non-smokers (\%) & $60 / 40$ & $53.3 / 46.7$ \\
\hline Staging (\%) & --- & 33.3 \\
\hline Stage IIA & -- & 43.4 \\
\hline Stage IIB & -- & 23.3 \\
\hline Stage III & & \\
\hline Histopathological type (\%) & --- & 53.4 \\
\hline Squamous cell carcinoma & --- & 23.3 \\
\hline Adenocarcinoma & --- & 23.3 \\
\hline Large cell carcinoma & $12.7 \pm 2.7$ & $11.2 \pm 2.8$ \\
\hline Hb, g/dl, & $4.6 \pm 3.7$ & $4.2 \pm 3.9$ \\
\hline RBCs (10 $\left./ \mathrm{mm}^{3}\right)$, & $6.1 \pm 3.7$ & $13.5 \pm 3.2^{* *}$ \\
\hline WBCs(103/mm $\left.{ }^{3}\right)$, & $233 \pm 3.1$ & $338 \pm 2.2^{\star *}$ \\
\hline Platelet (10 $\left./ \mathrm{mm}^{3}\right)$, & $5.2 \pm 2.7 / 10.7 \pm 2.2$ & $77.6 \pm 6.7 / 107 \pm 5.78^{* *}$ \\
\hline ESR(1h/ 2h) & $1.01 \pm 2.1$ & $1.0 \pm 1.9$ \\
\hline Serum creatinine & $18.2 \pm 3.8$ & $18.88 \pm 3.4$ \\
\hline Liver function & $15.02 \pm 1.4$ & $16.09 \pm 1.8$ \\
\hline AST (U/I) & & \\
\hline ALT (U/I) & & \\
\hline
\end{tabular}

$\mathrm{Hb}=$ heamoglobin, $\mathrm{WBC}=$ white blood cells, ESR= Erythrocetic sedimentation rate, $\mathrm{AST}=$ alanine spartate, $\mathrm{ALT}=$ alanine transferase ${ }^{*}=\mathrm{P}<0.5 ;{ }^{* *}=\mathrm{P}<0.01$

Table 1: Demographic and hematological characteristics of controls and NSCLC patients before treatment.

\begin{tabular}{|l|l|l|}
\hline Variables & $\begin{array}{l}\text { smokers } \\
(\mathbf{n = 1 6})\end{array}$ & $\begin{array}{l}\text { nonsmokers } \\
(\mathbf{n}=14)\end{array}$ \\
\hline S.VEGF $(\mathbf{p g} / \mathrm{ml})$ & $342.04 \pm 157.66$ & $301.66 \pm 23.68^{*}$ \\
\hline S.bFGF $(\mathbf{p g} / \mathrm{ml})$ & $224.67 \pm 100.06$ & $222.63 \pm 18.28$ \\
\hline T.VEGF $(\mathbf{p g} / \mathrm{mg}$ protein) & $540.07 \pm 199.12$ & $543.22 \pm 195.40$ \\
\hline T.bFGF $(\mathbf{p g} / \mathrm{mg}$ protein) & $300.35 \pm 88.60$ & $299.67 \pm 97.20$ \\
\hline
\end{tabular}

VEGF = vascular endothelial growth factor, $b F G F=$ basic fibroblast growth factor ${ }^{*} \mathrm{p}<0.05$

Table 2: Serum (S) and tissue (T) levels (mean \pm SD) of VEGF, bFGF, in smoker and nonsmoker patients before treatment. 
Citation: Abdel Ghany SM, El Melegy NT, Mohamed-Hussein AAR, Hana RS (2011) Emerging Prognostic Biomarkers in Non Small Cell Lung Cancer Patients: Impact of Treatment with Nimesulide (COX-2 Inhibitor) Combined with Chemotherapy. J Pulmonar Respirat Med S5:003. doi:10.4172/2161-105X.S5-003

Page 3 of 6

in stage IIB in comparison to stage IIA, in adenocarcinoma compared to other types of NSCLC and in large cell carcinoma in comparison to squamous cell carcinoma (Figures 2,3).

Furthermore, the serum and tissue levels of VEGF, bFGF, decreased significantly in the responders compared to resistant cases. The total number of responders was 18 cases $(60 \%)$, the response rate after chemotherapy alone was 53\% (9 cases out of 17), whereas the response rate after the combined therapy was $69 \%$ (9 cases out of 13) (Table 3). The sensitivity and specificity of serum VEGF were $100 \%$ and $80 \%$ (cut off value $=160$, area under the curve $=0.847$ ), while the sensitivity and specificity of serum bFGF were $100 \%$ and $100 \%$ (cut off value $=15$, area under the curve 1.0) as lung tumor markers in patients before treatment.

Finally, 5 patients from Group I died (29\%) after a period of 6.6 months while 3 patients from group II (23\%) died after 9.7 months.
No recorded data concerning the rest of patients indicating their death (Table 4).

\section{Discussion}

The results of the current study showed significantly higher serum and tissue levels of VEGF in NSCLC patients as compared to the control levels. These results agree with many authors [5,6,12-17]. Vascular endothelial growth factor is the most potent and specific endothelial cell mitogen. It promotes vascularization, vascular permeability, and growth of primary tumour and provides a pathway for migrating tumour cells to gain access to the systemic circulation [6-18]. Interestingly, in this study, 3 patients developed pleural effusion and this may explain the strong role of VEGF in inducing vascular hyperpermiability which is implicated also in lymphatic spread and in turn patient's prognosis [19-20]. The findings of the present study showed also that VEGF levels in serum and tissue decreased significantly after treatment as compared

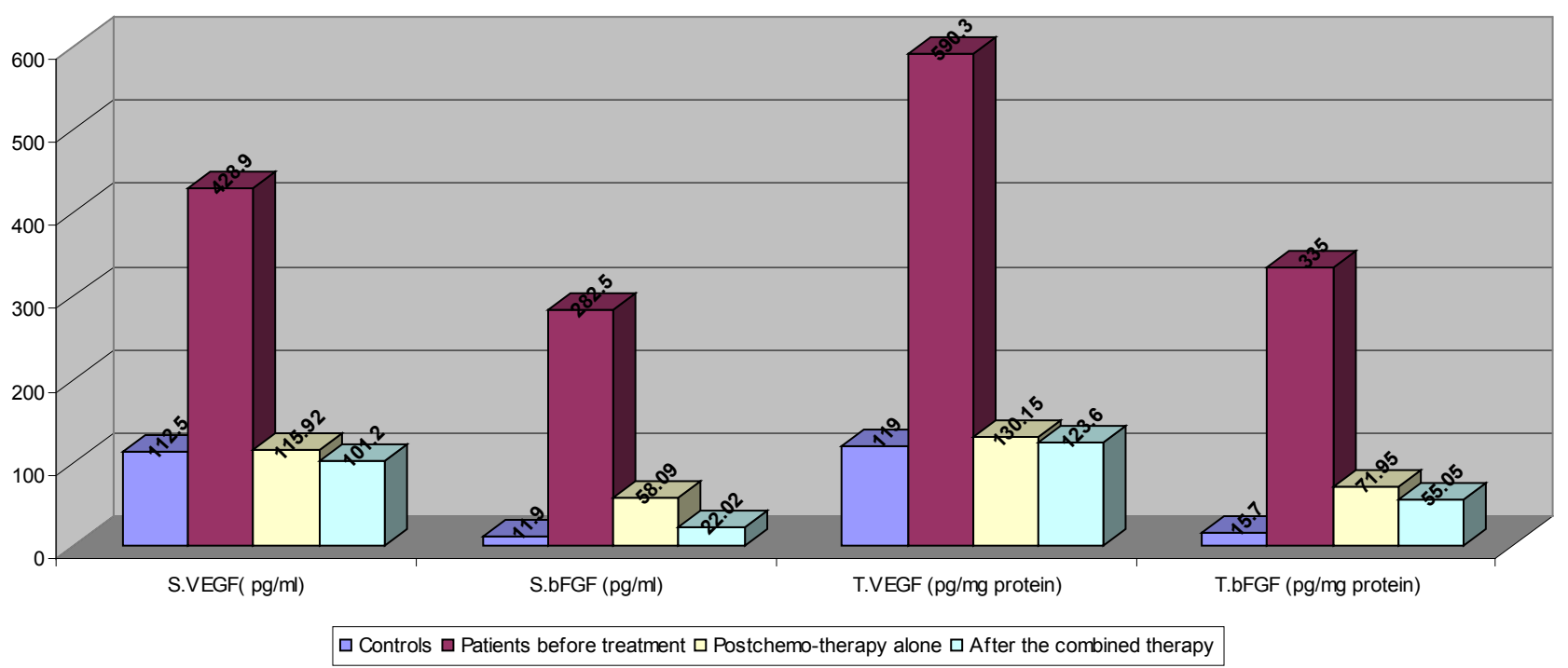

Figure 1: Serum (S) and tissue $(\mathrm{T})$ levels of the studied biochemical indices in controls and patients before and after therapy.

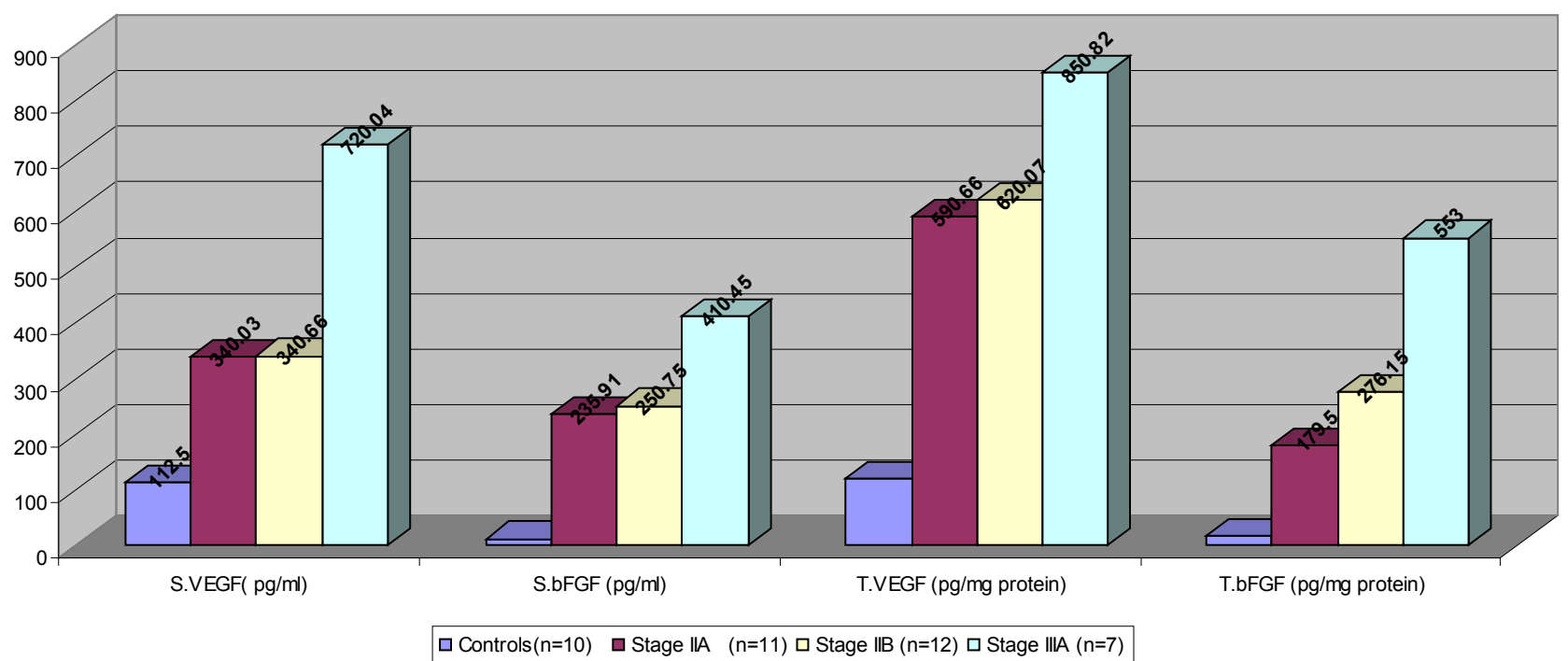

Figure 2: Serum $(\mathrm{S})$ and tissue $(\mathrm{T})$ levels of the studied biochemical markers in controls and stage IIA, IIB, IIIA NSCLC before therapy. 
Citation: Abdel Ghany SM, El Melegy NT, Mohamed-Hussein AAR, Hana RS (2011) Emerging Prognostic Biomarkers in Non Small Cell Lung Cancer Patients: Impact of Treatment with Nimesulide (COX-2 Inhibitor) Combined with Chemotherapy. J Pulmonar Respirat Med S5:003. doi:10.4172/2161-105X.S5-003

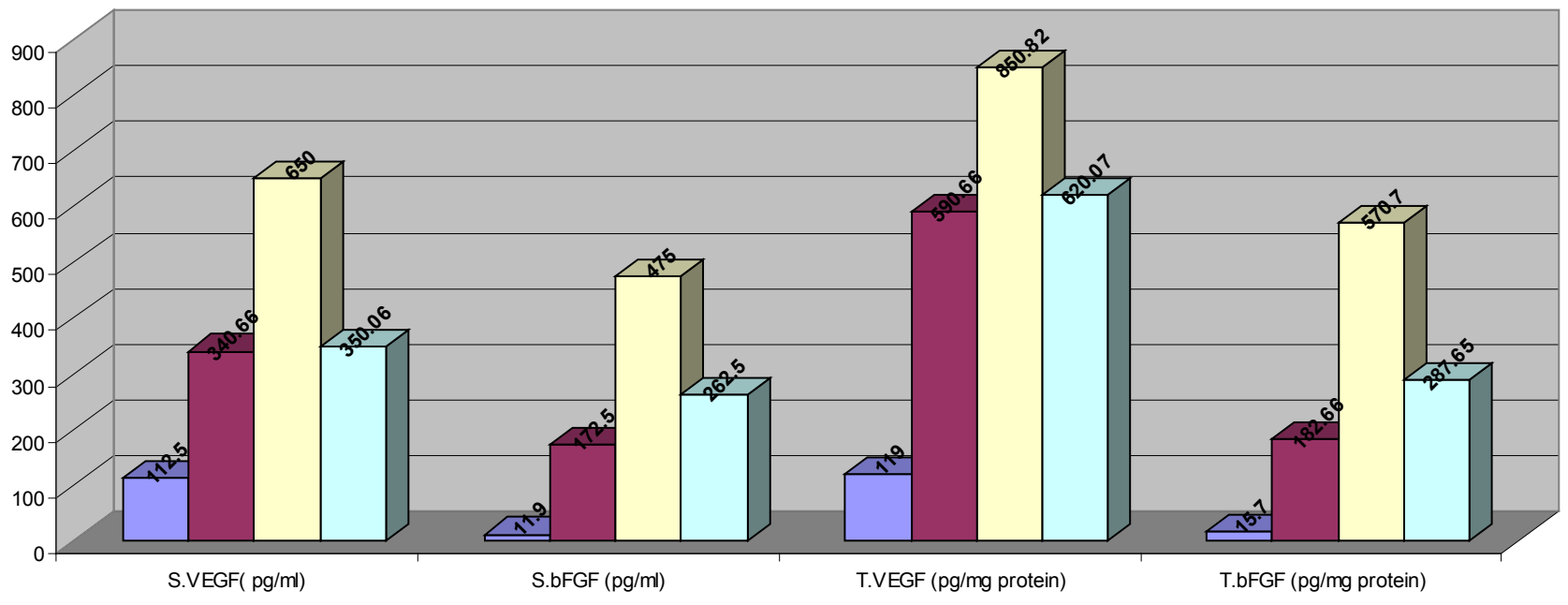

$\square$ Controls $(n=10) \square$ Squamous cell carcinoma $(n=16) \square$ Adenocarcinoma $(n=7)$ a large cell carcinomas $(n=7)$

Figure 3: Serum (S) and tissue (T) levels of the studied biomarkers in different Histopathological types of NSCLC.

\begin{tabular}{|c|c|c|}
\hline Indices & $\begin{array}{l}\text { Responder cases }(n=18)(9 \text { postchemotherapy and } 9 \text { after } \\
\text { the combined therapy ) }\end{array}$ & $\begin{array}{l}\text { Resistant cases }(n=12) \text { ( } 8 \text { postchemotherapy and } 4 \text { after the } \\
\text { combined therapy) }\end{array}$ \\
\hline S.VEGF (pg/ml) & $100.92 \pm 22.50$ & $115.2 \pm 28.60^{*}$ \\
\hline S.bFGF ( pg/ml) & $22.02 \pm 6.50$ & $55.09 \pm 8.60^{* *}$ \\
\hline T.VEGF (pg/ mg protein) & $122.66 \pm 22.60$ & $130.15 \pm 24.60^{* *}$ \\
\hline T.bFGF (pg/mg protein) & $52.05 \pm 9.60$ & $70.95 \pm 11.20^{*}$ \\
\hline
\end{tabular}

*: $p<0.05 * *: p<0.01$

Table3: Serum (S) and tissue $(T)$ levels (mean \pm SD) of VEGFand bFGF in responder and resistant cases.

\begin{tabular}{|l|l|l|l|}
\hline & CHEMOTHERAPY ALONE & COMBINED THERAPY & P VALUE \\
\hline Number of deaths, $\mathrm{n} \%$ & $5(29 \%)$ & $3(23 \%)$ & 0.04 \\
\hline Survival, month(mean \pm SD) & $6.6 \pm 1.3$ & $9.7 \pm 2.8$ & $<0.05$ \\
\hline
\end{tabular}

Table 4: Number of deaths and survival time in the studied groups.

to their pretreatment levels and in the combined therapy with Nimesulide compared to those with chemotherapy only. These results are supported with that of Brattstrom et al. [13] who concluded that both S.VEGF and bFGF are of clinical interest as prognostic indicators. The decrement in these levels was attributed to the regression of the established tumors and the response to treatment [21-23]. Many investigators showed that high levels of COX-2 expressions in NSCLC tissues (especially in adenocarcinoma and squamous cell carcinoma) was associated with the degree of tumor cell differentiation and depth of invasion. They suggested that, angiogenesis is attributed to COX-2 expression, that was significantly associated with increasing expression of VEGF, production of $\mathrm{PG}-\mathrm{E}_{2}, \mathrm{PG}-\mathrm{I}_{2}$ which can directly stimulate endothelial cell migration and VEGF-stimulated lymphangiogenesis besides, inhibition of apoptosis by stimulating $\mathrm{bcl}_{2}$ and suppression of antitumor immunity [2,22,24-26]. The COX-2 target therapy blocks the prostaglandins production leading to both anti-inflammatory and anti angiogenic effects. Recently, there is an epidemiologic evidence of a decreased incidence of lung cancer in patients using non steroidal anti-inflammatory drugs (NSAID) [22].

Nimesulide is a safe, well tolerated, cheap NSAID with selective COX-2 inhibition and emerging as a new approach with other COX2 inhibitor-drugs under trial in cancer treatment [1,27]. Similar to the present study, Cerchietti et al. [28] studied the effect of COX -2 inhibitors as anti-cancer agents and as adjuvant therapy and found that they are more potent than chemotherapy alone in inducing apoptosis of NSCLC cells and improving patients survival. In addition, Gadgeel et al. [29] demonstrated the effectiveness of the dual blockade of epidermal growth factor receptor (EGFR) and COX-2 in addition to conventional chemotherapy in NSCLC.

The current study showed that the VEGF levels were significantly higher in stage III A than those of stage, in stage IIB than stage IIA. These results agree with several studies demonstrating that the positive expression levels of VEGF were closely associated with the tumor stage and the lymph node metastasis, correlated to patient prognosis and recommended its use for diagnosis and follow- up of patients with lung cancer $[2,15,16,30]$.

The data of the present study clearly showed that the levels of the studied parameters were significantly higher in adenocarcinoma than other types of lung carcinomas and a significant increase in serum and tissue b-FGF and tissue VEGF levels in large cell carcinoma compared to squamous cell carcinoma levels. This is consistent with the study of Yuan et al. [30] who reported increased VEGF-mRNA expression in adenocarcinoma lung tissues in comparison to other types, and attributed this to the high metastatic potential of adenocarcinoma [31]

In addition, the current study demonstrated significantly decreased 
Citation: Abdel Ghany SM, El Melegy NT, Mohamed-Hussein AAR, Hana RS (2011) Emerging Prognostic Biomarkers in Non Small Cell Lung Cancer Patients: Impact of Treatment with Nimesulide (COX-2 Inhibitor) Combined with Chemotherapy. J Pulmonar Respirat Med S5:003. doi:10.4172/2161-105X.S5-003

Page 5 of 6

serum and tissue levels of VEGF and bFGF in the responders compared to the resistant cases. The percentage of responders was $60 \%$ with a response rate of $53 \%$ after chemotherapy only and $69 \%$ after the combined therapy. These results are in harmony with many reports suggesting that the decrease in serum VEGF levels may predict the improvement of angiogenesis and tumor response which correlate with the survival of the patients [31,32]. In contrast, abnormally unchanged high VEGF levels appear to be associated with poor prognosis [31] and worse survival rate [3].

The development of resistance to NSCLC treatment is one of the main factors affecting patient's survival. However, even in those resistant cases, the observed increased levels of many biomarkers may predict a slow response to the treatment. Lissoni et al. [14] observed that the one year survival rate was significantly higher in patients with treatment- induced normalization of VEGF than in those with persistently high VEGF levels. The anti-angiogenic agents as a treatment modality in NSCLC act to prune and normalize the vascular supply that is typically aberrant in tumors, thus, inhibiting VEGF can counter tumor resistance to chemotherapy, radiotherapy and improve prospects for such patients $[10,33]$.

The slow response of some NSCLC may be attributed to inherited VEGF-gene sequence variation which characterizes the tumor genome itself, the phenotype of NSCLC; the non angiogenic phenotype of some NSCLC may render them particularly difficult to treat with antiangiogenic drugs. So, genetic analysis of tumors may improve their diagnostic accuracy as well as efficacy and safety of treatment in the future [15].

In the current study 5 patients from Group I died (29\%) after a period of 6.6 months while 3 patients from group II (23\%) died after 9.7 months. No recorded data concerning the rest of patients indicating their death. This may show the favorable effect of COX-2 inhibitor (Nimesulide) in enhancing the survival rate of patients.

In the present study, the serum and tissue levels of bFGF were significantly higher in NSCLC patients compared to those of controls. These results agree with that reported by previous studies [34,35]. Akashi et al. [34] demonstrated that the proliferation of fibroblasts in the lung carcinomas is an important phenomenon that correlates with metastasis and poor prognosis They attributed this to the paracrine effects between cancer cells and fibroblasts via the fibrogenic cytokines "bFGF" that promotes growth and metastasis of lung cancer cells through a strong binding capacity to the basement membrane.

The current study revealed that the bFGF levels significantly decreased in cases receiving chemotherapy combined with Nimesulide as compared to their levels in patients before treatment and after chemotherapy only. It has been shown that bFGF is the most sensitive marker of recurrence after resection in early NSCLC [36]. Singh et al. [37] studied the effect of silibinin (a flavonone from milk thistle and a COX-2 inhibitor) on the growth and progression of primary lung tumors. They found that silibinin inhibits the growth of primary lung tumors and decreased lung tumor expression of VEGF and bFGF.

Also, the present study showed significantly higher levels of bFGF were in stage IIIA compared to stage II patients, in adenocarcinoma compared to squamous cell carcinoma group. These results are in accordance with that of Woenckhaus et al. [38] who demonstrated that the expression of beta-catenin, and bFGF were correlated to the clinicopathologic features, staging, clinical outcome and prognosis of NSCLC patients.

Lastly, the measured levels of VEGF, and bFGF, were sensitive, specific indicators for detection of NSCLC the studied patients and could be used as useful prognostic biomarkers for monitoring tumor progression. This is supported by the result of [38-40].

In conclusion, Nimesulide (the antiangiogenic selective COX-2 inhibitor) appears to boost the efficacy of the traditional chemotherapy as their co-administration showed encouraging effects on improving and normalization of the proangiogenic parameters levels and this may have good impact on the patient outcome and prolongation of their survival rate. In addition, the angiogenic factors namely VEGF, bFGF proved to be sensitive parameters as regarding NSCLC patients prognosis.

\section{Conflict of Interest}

The authors have no actual or potential conflict of interest or financial, personal or other relationships with other people or organizations that could inappropriately influence this work.

\section{References}

1. Cappuzzo F, Bartolini S, Crino L (2003) Emerging drugs for non-small cell lung cancer. Expert Opin Emerg Drugs 8: 179-192.

2. Guo X, Chen Y, Xu Z, XuZ, Qian Y, et al. (2009) Prognostic significance of VEGF-C expression in correlation with COX-2, lymphatic microvessel density, and clinicopathologic characteristics in human non-small cell lung cancer. Acta Biochim Biophys Sin 41: 217-222.

3. Maekawa S, Iwasaki A, Shirakusa T, Enatsu S, Kawakami T, et al. (2007) Correlation between lymph node metastasis and the expression of VEGF-C VEGF-D and VEGFR-3 in T1 lung adenocarcinoma. Anticancer Res 27: 37353741 .

4. Ferrera N (2004) VEGF as a target for anticancer therapy. The oncologist 9 2-10.

5. El- Melygy N, Mohamed-Hussein A (2005) Tissue levels of platelet- derived endothelial cell growth factor (thymidine phosphorylase), vascular endothelial growth factor and cathepsin-D in patients with bronchogenic carcinoma. The Arab Journal of Laboratory Medicine 31: 204-207.

6. Li CY, Shan S, Huang Q, Braun RD, Lanzen J, et al. (2000) Initial stages of tumor cell-induced angiogenesis: evaluation via skin window cambers in rodent models. J Natl Cancer Inst 92: 143-147.

7. Zimering MB, Thakkr-Varia S (2002) Increased basic fibroblast growth factor (bFGF) in serum of cancer patients. Life Sci 25: 2939-2959.

8. Sardari Nia P, Colpaert C, Vermeulen P, Weyler J, Pezzella F, et al. (2008) Different growth patterns of non-small cell lung cancer represent distinct biologic subtypes. Ann Thorac Surg 85: 395-440.

9. Abdollahi A, Lipson KE, Sckell A, Zieher H, Klenk F, et al. (2003) Combined therapy with direct and indirect angiogenesis inhibition results in enhanced antiangiogenic and antitumor effects. Cancer res 63: 8890-8898.

10. Herbst RS, Sandler AB (2004) Non-small cell lung cancer and antiangiogenic therapy: what can be expected of bevacizumab? Oncologist 9: 19-26.

11. Lawery OH, Rosenbrough NJ, Farr AL, Randall RJ (1951) Protein measurement with Folin phenol reagent. J Biol Chem 1: 193-265.

12. Kido Y Ishikawa T, Kawano T, Sugihara K (2001) SVEGF Changes during chemotherapy in NSCLC. Kurume Med J 48: 43-47.

13. Bashkin P, Doctrow S, Klagsbrun M, Svahn CM, Folkman J, et al. (1989) Basic fibroblast growth factor binds to subendothelial extracellular matrix and is released by heparitinase and heparin-like molecules. Biochemistry 28: $1737-$ 1743

14. Lissoni P, Rovelli F, Malugani F, Brivio F, Fumagalli L, et al. (2003) Changes in circulating VEGF levels in relation to clinical response during hemotherapy for metastatic cancer. Int J Biol Markers 18: 152-155.

15. Kaya A, Ciledag A, Gulbay BE, Poyraz BM, Celik G, et al. (2004) The prognostic significance of vascular endothelial growth factor levels in sera of non-small cell lung cancer patients. Respir Med 98: 632-636.

16. Katsabeki-Katsafli A, Kerenidi T, Kostikas K, Dalaveris E, Kiropoulos TS, et al (2008) Serum vascular endothelial growth factor is related to systemic oxidative stress in patients with lung cancer. Lung Cancer. 31: 7136-7142. 
Citation: Abdel Ghany SM, El Melegy NT, Mohamed-Hussein AAR, Hana RS (2011) Emerging Prognostic Biomarkers in Non Small Cell Lung Cancer Patients: Impact of Treatment with Nimesulide (COX-2 Inhibitor) Combined with Chemotherapy. J Pulmonar Respirat Med S5:003. doi:10.4172/2161-105X.S5-003

Page 6 of 6

17. Choi BM, Kim HJ, Oh GS, Pae HO, Oh H, et al. (2009) 1,2,3,4,6-Penta-Ogalloyl-beta-D-glucose protects rat neuronal cells (Neuro $2 \mathrm{~A}$ ) from hydrogen peroxide-mediated cell death via the induction of heme oxygenase-1. Neurosci Lett 328: 185-189.

18. Criscuoli ML, Nguyen M, Eliceiri BP (2005) Tumor metastasis but not tumo growth is dependent on Src-mediated vascular permeability. Blood 105: 1508 $-1514$

19. Maekawa S, Iwasaki A, Shirakusa T, Enatsu S, Kawakami T, et al. (2007) Correlation between lymph node metastasis and the expression of VEGF-D and VEGFR-3 in T1 lung adenocarcinoma. Anticancer Res 27: 3735-3741.

20. Lemarie E (2007) Stage IV non small cell bronchial carcinoma; first line therapy in 2007. Rev Mal Respir 24: 6S101-6S107.

21. Yashimoto A, Kasahara K, Kawashima A, Fujimura M, Nakao S (2005) Characterization of the prostaglandin biosynthetic pathway in non- small cel lung cancer: a comparison with small cell lung cancer and correlation with angiogenesis, angiogenic factors and metastases. Oncol Rep 13: 1049-1057.

22. Sandler AB, Dubinett SM (2006) COX-2 inhibition and lung cancer. Semin Oncol 31: 45-52.

23. Naumnik W, Izycki T, Swidzińska E, Ossolińiska M, Chyczewska E (2008) Serum levels of VEGF-C, VEGF-D, and sVEGF-R2 in patients with lung cancer during chemotherapy. Oncol Res 16: 445-451.

24. Saukkonen K, Rintahaka J, Sivula A, Buskens CJ, Van Rees BP, et al. (2003) Cyclooxygenase-2 and gastric carcinogenesis. APMIS 111: 915-925.

25. Kolev Y, Uetake H, lida S, Ishikawa T, Kawano T, et al. (2008) COX-2 expression correlates with severity of cervical cancer precursor (CIN) lesions and invasive disease. Ann Surg Oncol 14: 2738-2747.

26. Hammam OA, Aziz AA, Roshdy MS, Abdel Hadi AM (2008) Possible role of cyclooxygenase-2 in schistosomal and non-schistosomal-associated bladder cancer. Medscape J Med 10: 60.

27. Kerbal RS (2008) Tumor angiogenesis. N Engl J Med 358: 2039-2049.

28. Cerchietti LC, Navigante AH, Castro MA (2007) Effects of eicosapentaenoic and docosahexaenoic n-3 fatty acids from fish oil and preferential Cox-2 inhibition on systemic syndromes in patients with advanced lung cancer. Nutr Cancer 59: 14-20.

29. Gadgeel SM, Ruckdeschel JC, Heath El, Heilbrun LK, Venkatramanamoorthy
$R$ et al. (2007) Phase II study of gefitinib, an epidermal growth factor recepto tyrosine kinase inhibitor (EGFR-TKI), and celecoxib, a cyclooxygenase-2 (COX-2) inhibitor, in patients with platinum refractory non-small cell lung cancer (NSCLC). J Thorac Oncol 2: 299-305.

30. Yuan R, Kawano Y, Miyahara R (2009) The role of VEGF in NSCLC. Int $J$ Cancer 89: 475-483.

31. Lissoni P, Rovelli F, Malugani F, Brivio F, Fumagalli L, et al. (2003) Changes in circulating VEGF levels in relation to clinical response during chemotherapy for metastatic cancer. Int J Biol Markers 18: 152-155.

32. Kido Y Ishikawa T, Kawano T, Sugihara K (2001) SVEGF Changes during chemotherapy in NSCLC. Kurume Med J 48: 43-47.

33. Viloria-Petit A, Crombet T, Jothy S, Hicklin D, Bohlen P, et al. (2001) Acquired resistance to the antitumor effect of epidermal growth factor receptor-blocking antibodies in vivo: a role for altered tumor angiogenesis. Cancer Res 61: 5090 5101.

34. Akashi T, Minami J, Ishige Y, Eishi Y, Takizawa T, et al. (2005) Basement membrane matrix modifies cytokine interactions between lung cancer cells and fibroblasts. Pathobiology 72: 250-259.

35. Kaminska J, Kowalska M, Kotowicz B, Fuksiewicz M (2006) Pretreatment serum levels of cytokines and cytokine receptors in patients with non-small cel lung cancer, and correlations with clinicopathological features and prognosis. M-CSF-an independent prognostic factor. Oncology 70: 115-125.

36. Liu Y (2009) Association between glutathione S-transferase pi polymorphism and survival in patients with advanced nonsmall cell lung carcinoma. Cancer 2: 441-444.

37. Singh A, Bing H, George T, Gupta S, Roberts B, et al. (2005) Glutathione-linked detoxification pathway in normal and malignant human bladder tissue. Eur Uro 47: 703-709.

38. Woenkhaus MJ, Edelman M, Valdivieso L, Heilbrun R (2008) VEGF recepto 1,2 , and 3 inhibitor in patients with recurrent non-small cell lung cancer. Lung cancer 10: 39-42.

39. Kakair KJ, Li B, Winer J (1999) BFGF expression in human lung cancer. Nature 362: $841-848$.

40. Zhang S, Zhu Y, Tu C, Wei H, Yang Z, et al. (2004) A novel cytotoxic ternary copper(II) complex of 1,10-phenanthroline and L-threonine with DNA nuclease activity. J Inorg Biochem 12: 2099-2106.
This article was originally published in a special issue, Lung Cance Challenges to the future handled by Editor(s). Dr. Ramon Andrade de Mello, University of Porto, Portugal 